\title{
UV researchers opt for a compromise
}

\section{Washington}

WHEN researchers reported earlier this winter that ozone loss had reached record levels at both poles, the US public wanted to know one thing: Were levels of the most harmful ultraviolet radiation (UV-B) going up as the ozone layer became thinner?

Good question. But despite a UV monitoring network that has been in place for more than 20 years, researchers still have no good answer. The problem is that the existing monitors (known as Robertson -Berger meters) were designed to give a broad 'sunburn equivalent' reading. They are not sensitive enough to differentiate between UV-A radiation, which is believed to stimulate cell repair, from UV-B, which damages living tissue. Worse, most of the monitors are in urban areas, where the ozone that is pumped into the lower atmosphere from man-made pollutants often cuts out much of the UV radiation that penetrates the stratospheric ozone.

Last week, a group of researchers met in Washington, DC, to design a better system. Researchers sponsored by the US Department of Agriculture (USDA) have developed a more sensitive UV monitor, and the agency wanted advice on just how and where the new monitors should be deployed. For one thing, the new monitors will be expensive (more than $\$ 100,000$ each at the moment) and they may not be available in quantity for several years. The agency hopes eventually to have at least six monitors in the continental United States as part of its $\$ 3$ million programme.

Deciding where to place them will not be easy. The first one will almost certainly join other monitors at a Department of Energy experimental station on the Kansas-Oklahoma border, where the UV reading can be correlated with other radiation and atmospheric measurement. Others could be in almost any rural area, however, and it is not clear just what kind of geographic location would give the most useful measurements. For example, researchers do not know if two locations just a few hundred miles apart would produce significantly different readings.

To answer some of these questions, the scientists at last week's meeting proposed something of a stopgap solution: deploy
10-15 meters similar to the old Robertson -Berger monitors in the sort of locations in which USDA would like to put the more sophisticated monitors. They are expected to make such a recommendation in a report that will go to USDA in early summer.

But some researchers are concerned that this approach does not tackle the problem head-on. They point out that other countries, including Canada, New Zealand and Australia, are taking good measurements with high-quality scanning spectral radiometers that are already available.

James Gibson, a Colorado State University researcher who led last week's conference, has heard this complaint before. He was involved in the 10-year, congressionally mandated acid rain assessment project that spent so long perfecting its research that legislation was passed before its final report was released in 1990 . He says that the Robertson-Berger solution appears to be the best compromise between waiting for the best possible measurements and leaping in with cheap monitors now.

Christopher Anderson

\section{FBI investigating NIH leaks}

\section{Washington}

THE US Federal Bureau of Investigation (FBI) is looking into allegations that current and former employees of the National Institutes of Health's (NIH) misconduct office have leaked documents relating to the agency's investigation of scientific misconduct. The FBI's actions, in turn, have triggered a new investigation of $\mathrm{NIH}$ by Representative John Dingell (Democrat, Michigan).

For the benefit of those who are still keeping score, that makes it Congress investigating NIH's investigation of a former employee's investigation of NIH's investigations of misconduct. Ironically, by the time all this is over, the misconduct office is expected to be history (see page 191).

Last week, an FBI agent interviewed Suzanne Hadley, the former deputy director of the NIH Office of Scientific Integrity (OSI), who has since turned whistleblower and is working part-time with a congressional investigations subcommittee that Dingell chairs. According to Hadley, the agent told her that he was looking into allegations that "documents were walking out of OSI" and that the FBI had interviewed several OSI employees who had admitted giving documents to Hadley. The agent did not identify a specific crime that the FBI was investigating.

Although Hadley declined to answer questions without a lawyer present, she says that the FBI probe "is all innuendo. It has the feel of a fishing expedition." She denies taking documents, although she acknowledges that she has been given documents that have been leaked. The same could be said, of course, of reporters, the Dingell committee and many scientists.

Last week NIH replaced the locks on Hadley's office door "so that nothing is changed", says spokeswoman Joanna Schneider. Hadley will be given another office at NIH, she says.

$\mathrm{NIH}$ also changed the locks at OSI last week - the third time in the past two months. Officials first changed OSI's locks after the Chicago Tribune reported on a draft of a final report in the case of NIH AIDS researcher Robert Gallo, the fourth such leak in two years. Only after the article appeared did it occur to OSI officials that they had not changed the locks last July, when Hadley was reassigned to another part of NIH. Hadley says that, since then, she has entered OSI only once (and with an official escort). OSI changed its locks a second time after receiving a letter from Dingell complaining that the office had shredded sensitive documents.

$\mathrm{NIH}$ officials say the FBI investigation began when the OSI received a call from a former employee alleging that current employees were providing documents to Hadley. NIH took the allegations first to the Inspector General of its parent agency, the Department of Health and Human Serv- ices. But the Inspector General declined to investigate because of a possible conflict of interest with an ongoing investigation of $\mathrm{NIH}$. That inquiry is looking into allegations that NIH officials made false statements in connection with the 1984 US patent application for a blood test for the human immunodeficiency virus, which is based on the work of Gallo. The Inspector General then referred the case to the FBI. According to Hadley, the FBI agent said that NIH has determined that the leaks and their political fallout have paralysed OSI, rendering it "dysfunctional" and costing the agency $\$ 9,000$ per day.

Hadley alleges that the FBI investigation is just the latest example of a "harassment campaign" that NIH launched after Bernadine Healy, the NIH director, criticized her "lack of objectivity" in handling the misconduct case of Tufts University researcher Thereza Imanishi-Kari. This week, Hadley's attorney, Wayne Schrader of Gibson, Dunn and Crutcher, expects to file a complaint with the Office of Special Council (an independent US agency) alleging that $\mathrm{NIH}$ have violated the Whistleblower Protection Act in essentially demoting Hadley and making false statements about her. In a letter dated 12 March to Healy, Dingell called NIH's action an "apparent act of harassment and intimidation aimed at [a] courageous, public-spirited whistleblow[er]."

Christopher Anderson 